\title{
Bentonite Modified Carbon Paste Electrode as a Selective Electrochemical Sensor for the Detection of Cadmium and Lead in Aqueous Solution
}

\author{
Ali Ourari ${ }^{1, *}$, Farid Tennah ${ }^{1,2}$, Ramiro Ruíz-Rosas ${ }^{2}$, Djouhra Aggoun, ${ }^{1, *}$, Emilia Morallón $^{2}$ \\ ${ }^{1}$ Laboratoire d'Electrochimie, d'Ingénierie Moléculaire et de Catalyse Redox (LEIMCR), Faculté de \\ Technologie, Université Setif-1, Setif 19000, Algeria. \\ ${ }^{2}$ Instituto Universitario de Materiales, Universidad de Alicante, Ap. 99. E-03080 Alicante, Spain. \\ *E-mail: alourari@yahoo.fr (A. Ourari); aggoun81@yahoo.fr (Dj. Aggoun)
}

doi: $10.20964 / 2018.02 .35$

Received: 25 October 2017 / Accepted: 12 December 2017 / Published: 28 December 2017

\begin{abstract}
This work describes the use of a carbon paste electrode (CPE) modified with a Bentonite clay (Maghnite) as an electrochemical non-pollutant, selective and low cost sensor for Cadmium and Lead detection in aqueous solution. The physico-chemical properties of the clay mineral were analysed by X-Ray Fluorescence analysis (XRF), Powder X-ray diffraction (XRD), Thermogravimetric analysis (TG) and $\mathrm{N}_{2}$ adsorption isotherm. The square wave anodic stripping voltammetry (SWASV) has been used in which the different electrochemical parameters have been studied. The optimal preconcentration $\mathrm{pH}$ and Maghnite-CPE content were found to be 3.4 and $14 \% \mathrm{w} / \mathrm{w}$ respectively. Under these optimized conditions and at a preconcentration time of $5 \mathrm{~min}$, the response of the electrode was linear with analytes concentration in the ranges from 1 to $30 \mu \mathrm{mol} / \mathrm{L}$ for Cadmium and 0.1 to $30 \mu \mathrm{mol} / \mathrm{L}$ for Lead with limit of detection (LOD) values of $0.16 \mu \mathrm{mol} / \mathrm{L}$ and $0.30 \mu \mathrm{mol} / \mathrm{L}$ for Cadmium and Lead respectively.
\end{abstract}

Keywords: Bentonite (Maghnite), Carbon paste electrode (CPE), Anodic stripping voltammetry (ASV), Square wave voltammetry (SWV), Electrochemical sensor, Cadmium and Lead.

\section{$\underline{\text { FULL TEXT }}$}

(C) 2018 The Authors. Published by ESG (www.electrochemsci.org). This article is an open access article distributed under the terms and conditions of the Creative Commons Attribution license (http://creativecommons.org/licenses/by/4.0/). 